\title{
MODERN METHODS AND TECHNOLOGIES FOR DEVELOPING PRE-SERVICE FOREIGN LANGUAGE AND CULTURE TEACHERS' METHODOLOGICAL COMPETENCE
}

\author{
Nataliia Maiier \\ Kyiv National Linguistic University, Kyiv, Ukraine \\ n.maiier@knlu.edu.ua \\ Olga Ustymenko \\ Kyiv National Linguistic University, Kyiv, Ukraine \\ ustymenko@knlu.edu.ua
}

\begin{abstract}
Methodological training of pre-service foreign language and culture teachers is a top priority in pedagogical education nowadays. In this article, methodological competence is determined as methodological knowledge and methodological skills that provide the ability and willingness of pre-service foreign language and culture teachers to execute all types of their professional activities. To facilitate methodological knowledge acquisition, the authors suggest applying the test method and information \& communication technologies (ICT). This paper substantiates the expediency of using a case study method for building Master's students' methodological skills of analysing and correcting methodological errors, creating foreign language lesson plans for integrated developing of linguistic, discourse, lingua-socio-cultural, and strategic competencies. Professional methodological cases are considered as the means of implementing a case study method in teacher training process. Game method, namely professional roleplaying games, are employed to foster Master's students' methodological skills to prepare and teach lessons for integrated reinforcement of linguistic, discourse, lingua-socio-cultural, and strategic competencies. We recommend using a project-based method to train pre-service foreign language and culture teachers to choose and select course materials, devise activities, exercises, games, aids, case studies, tests, assessments, project-based tasks, etc. Professional methodological projects are used as the instruments for applying a project-based method in teacher training at tertiary schools. On the basis of their experimental experience, the researchers substantiate the efficiency of using test method, case study method, game method, project-based method, and ICT for developing a methodological competence of pre-service foreign language and culture teachers as well as demonstrate some practical aspects of implementing these methods and technologies in the educational process. 167 Master's students of Kyiv National Linguistic University participated in the experiment which was held in 2016-2018. The experimental teaching resources consisted of tests for students' autonomous methodological knowledge acquisition in the course of their self-guarded extracurricular work in Moodle and professional methodological assignments with the use of the aforementioned methods. The analysis of experimental data showed that altogether test method, case study method, game method, project-based method, and ICT contribute significantly to developing pre-service foreign language and culture teachers' methodological competence. The issues and findings raised in the article indicate that larger implications of this research and avenues for further studies are connected with substantiating the structure and content of the electronic course book for pre-service foreign language and culture teachers aimed at developing their methodological competence with the use of modern educational methods and technologies.
\end{abstract}

Keywords: pre-service foreign language and culture teachers; methodological teacher training; methodological competence; methodological knowledge; methodological skills; test method; self-guarded knowledge acquisition; ICT; case study method; professional methodological case; game method; professional methodological role-playing game; project-based method; professional methodological project; evaluation criteria.

\section{Introduction}

Modern trends in pedagogical education require new priorities for methodological training of preservice foreign language and culture teachers. In view of this, we consider methodological teacher training as "mastering by pre-service specialists a system of competencies focused on the organisation of the teaching foreign language process" (Nikitina, Afanaseva, \& Fedotova, 2013, p. 56).

Language teacher training results in pre-service teachers' methodological competence, which we define as their ability and readiness to implement in foreign language and culture education all types of professional methodological activities. We must mention that in this article, sharing the view of Malyov (2015), we do not distinguish the concept "teacher" among different educational levels as semantically the notion of language teaching reflects one's expertise in language education at any educational stage (p. 5).

The competency paradigm of methodological teacher training determines the development and implementation of methods and technologies that would ensure gradual students' methodological knowledge acquisition as one of the components of their methodological competence. To methodological knowledge we refer the following aspects: 1) declarative knowledge of the system and process of developing a crosscultural professional foreign language communicative competence; 2) procedural knowledge of methods, technologies, and techniques of its reinforcement. Methodological skills include teacher's ability to execute deliberately and independently his/her professional activities for developing students' cross-cultural foreign 
language communicative competence on the basis of the acquired methodological knowledge in new professional situations.

Researchers emphasise that contemporary tertiary schools need more active, group, game, role-playing, practical, problem, reflexive, and other teaching methods and educational technologies (Stanley, 2013; Vacca, 2014; Williams, 2009; Yurlovskaya, 2014). To paraphrase the definition of language teaching methods (Azimov \& Schukin, 2009, p. 165; Richards, Platt, \& Platt, p. 330), we interpret methods for developing methodological competence as a range of techniques, procedures, modes, and means of teacher's and student's activities aimed at achieving educational goals and subsequent designing of the teacher training process.

Thus, the objectives of this article are 1) to substantiate expediency and efficiency of using such modern methods and technologies as test method, case study method, game method, project-based method, and ICT for developing a methodological competence of pre-service foreign language and culture teachers; and 2) taking into consideration the authors' experimental experience, to demonstrate some practical aspects of implementing these methods in the educational process.

\section{Methods}

\section{Participants}

167 Master's students of Kyiv National Linguistic University majoring in philology and foreign language and culture teacher training took part in this educational investigation. The experimental training was conducted during 2016-2017 and 2017-2018 academic years. The participants were divided into four experimental groups.

\section{Apparatus and materials}

The experimental teaching resources consisted of 1) tests for students' autonomous methodological knowledge acquisition in the course of their self-guarded extracurricular work and 2) professional methodological tasks and activities with the use of different educational methods and technologies designed by the authors of this paper. Examples of teaching materials created by the researchers are provided in Appendices 1-3.

\section{Procedure}

The educational research comprised defining and redefining research problems; formulating hypotheses and suggesting solutions; collecting, organising, and evaluating data; making deductions and reaching conclusions; testing the conclusions to determine whether they fit the formulated hypotheses.

Comparison and analysis of previous theoretical studies, generalisation of positive experience in preservice foreign language and culture teacher training, monitoring the educational process allowed the authors to formulate primary and secondary research hypotheses. Primarily, it was hypothesised that the use of test method, case study method, game method, project-based method, and ICT can increase development efficiency of pre-service foreign language and culture teachers' methodological competence. To further explore the primary hypothesis, the researchers assumed that the factors affecting the choice of educational method and/or technology were predominated by such intermediate objectives of building prospective language teachers' methodological competence as their 1) methodological knowledge acquisition and 2) methodological skills mastering.

In this regard, the above-mentioned methods and technologies for developing distinct components of pre-service foreign language and culture teachers' methodological competence - methodological knowledge and methodological skills - were taken to be independent variables in the experiment.

The phases of the experiment were as follows: 1) hypotheses formulation, 2) teaching materials design, 3) experimental groups selection, 4) experimental training, 5) research data analysis.

The levels of methodological knowledge and skills among the participants were measured by the formula $\mathrm{K}=\mathrm{A} / \mathrm{N}$ where $\mathrm{K}$ is learning outcomes coefficient, $\mathrm{A}$ is the number of points received for correct answers, and $\mathrm{N}$ is a maximal number of points assigned for correct answers (Bespalko, 1968). The learning outcomes coefficient of 0.7 and higher was considered acceptable according to Cronbach's alpha coefficient of reliability (Cronbach, 1951).

\section{Results}

The aim of the research experiment was to verify and prove the advantage and effectiveness of applying test method, case study method, game method, project-based method, and ICT in building pre-service foreign language and culture teachers' methodological competence.

It is well-known that test method is used primarily to test students' knowledge. We recommend using ICT to test pre-service teachers' methodological knowledge. Moreover, in our experiment, we used test 
method for students to acquire methodological knowledge over their individual learning trajectories in the course of their self-guarded extracurricular work in Moodle. For example, we created test libraries for such academic disciplines as "Applying project-based approach in teaching foreign languages and cultures" (online classroom, archived at: http://m.knlu.edu.ua/course/view.php?id=959), "Modern approaches to French language testing" (online classroom, archived at: http://m.knlu.edu.ua/course/view.php?id=230), and "French language teaching methodology at tertiary schools" (online classroom, archived at: http://m.knlu.edu.ua/course/view.php?id=214).

We designed test items of different formats (Green, 2013) to advance students' command of methodological knowledge: multiple choice questions; alternative response tests; matching type tests (e.g. designating correlations between methodological concepts and their definitions, between language drills and stages of skill acquisition, between vocabulary items and the most appropriate ways of their semantisation (word denoting), between lesson plan objectives and their statements, etc.); cloze tests (completion type tests, information gap tests); tests of teacher's methodological actions rearrangement (reordering type tests); tests of error correction in academic texts on foreign language teaching theories, etc. The test question wordings we used was focused on personal interests of prospective language teachers, which, we believed, was a motivating factor for test doing and promoting students' self-reflection. Examples of experimental test questions are provided in Appendix 1.

Students' methodological knowledge acquisition results (Table 1) were measured on the basis of the evaluation criterion "correct answer to test question" (points were awarded for correct elements). Students of experimental groups 1 and 3 were running the proposed tests. Meanwhile, students of experimental groups 2 and 4 were gaining methodological knowledge during autonomous work with theoretical materials supplied by teacher trainers.

Table 1

Results of experimental participants' methodological knowledge acquisition

\begin{tabular}{|c|c|}
\hline Experimental groups & \multicolumn{1}{|c|}{ Learning outcomes coefficient } \\
\hline \multicolumn{2}{|c|}{$2016-2017$ academic year } \\
\hline Experimental group 1 & 0.74 \\
\hline Experimental group 2 & 0.64 \\
\hline Experimental group 3 & 0.85 \\
\hline Experimental group 4 & 0.67 \\
\hline
\end{tabular}

Consequently, the average coefficient of learning outcomes for experimental groups 1 and 3 reached 0.8 . For experimental groups 2 and 4 , it was 0.66 .

As a rule, researchers suggest using in foreign language classrooms such case studies as topics or topical keywords for discussions, texts for discussions, tasks for text discussions, themes for presentations at seminars, etc. (Azimov \& Schukin, 2009, p. 315; Heitzmann, 2008, pp. 526-530; Kelch \& Malupa-Kim, 2014, pp. 13-14) to provide students with essential professional knowledge.

To support our hypothesis that case study method contributes largely to pre-service foreign language and culture teachers' methodological skills development, we used a special mode for implementing case studies in our research - a professional methodological case. In our opinion, a professional methodological case is a naturalistic teaching performance situation used for building and improving pre-service teachers' methodological skills, abilities, and readiness to plan foreign language and culture learning activities. The sources for professional methodological case studies were real work situations. Methodological cases were presented to students in different formats: texts, videos, etc. Examples of experimental professional methodological cases are given in Appendix 2.

Experimental participants solved professional cases individually during their self-guarded learning and presented the obtained results at seminars on teaching foreign language and culture methods. More precisely, students of experimental groups 1 and 3 solved professional methodological cases, and students of experimental groups 2 and 4 performed standard methodological tasks on lesson analysis and lesson planning. The results of building pre-service foreign language and culture teachers' methodological skills to analyse lesson plans and videotaped lessons as well as to create classroom activities are summarised in Table 2. Besides, we would like to draw your attention to the fact that each of the proposed professional methodological cases was accompanied with relevant evaluation criteria used in the experimental research studies to determine the level of students' methodological skills attainment. 


\section{Results of experimental participants' methodological skills attainment}

\begin{tabular}{|c|c|}
\hline Experimental groups & Learning outcomes coefficient \\
\hline \multicolumn{2}{|c|}{$2016-2017$ academic year } \\
\hline Experimental group 1 & 0.72 \\
\hline Experimental group 2 & 0.66 \\
\hline Experimental group 3 & 0.75 \\
\hline Experimental group 4 & 0.63 \\
\hline
\end{tabular}

Thus, the average coefficient of learning outcomes for experimental groups 1 and 3 amounted to 0.74 . For experimental groups 2 and 4 , it was 0.65 .

We believe that simulations of real-life professional methodological situations, as well as students' learning to act in such situations, are possible, provided that game method, namely professional role-playing games, are used at seminars in the discipline "Methodology of teaching foreign languages and cultures". A professional role-playing game is a methodological technique for organising students' cooperative learning activities for mastering target methodological skills on the basis of scenario simulations of professional teaching actions.

At seminars, Master's students of experimental groups 1 and 3 presented their lesson plans acting as foreign language university teachers, while their fellow students played roles of Bachelor students. All roles were appointed by teacher trainers. The course and effects of such role-playings were subjects of whole class discussions held in full accordance with dialogic teaching principles. Students of experimental groups 2 and 4 prepared their lesson plans and submitted their assignments directly to teacher trainers. At their next seminar, students of groups 2 and 4 received trainers' feedback on their works.

In both variants, we used the following evaluation criteria: 1) the teaching/learning objectives statements are written accurately; 2) the lesson stages are relevant to the teaching objectives; 3 ) the chosen teaching methods and techniques are appropriate for the lesson objectives; 4) the language learning tasks are formulated properly; 5) the lesson plan is written in foreign and native languages clearly and accurately. The obtained coefficient indices are given in Table 3.

Table 3

Results of experimental participants' lesson planning skills attainment

\begin{tabular}{|c|c|c|}
\hline Evaluation criteria & Experimental groups & $\begin{array}{l}\text { Learning } \\
\text { outcomes } \\
\text { coefficient }\end{array}$ \\
\hline \multirow{6}{*}{$\begin{array}{l}\text { 1) the teaching/learning objectives } \\
\text { statements are written accurately }\end{array}$} & \multicolumn{2}{|c|}{ 2016-2017 academic year } \\
\hline & Experimental group 1 & 0.72 \\
\hline & Experimental group 2 & 0.6 \\
\hline & \multicolumn{2}{|c|}{ 2017-2018 academic year } \\
\hline & Experimental group 3 & 0.76 \\
\hline & Experimental group 4 & 0.69 \\
\hline \multirow{6}{*}{$\begin{array}{l}\text { 2) the lesson stages are relevant to the } \\
\text { teaching objectives }\end{array}$} & \multicolumn{2}{|c|}{ 2016-2017 academic year } \\
\hline & Experimental group 1 & 0.77 \\
\hline & Experimental group 2 & 0.59 \\
\hline & \multicolumn{2}{|c|}{ 2017-2018 academic year } \\
\hline & Experimental group 3 & 0.71 \\
\hline & Experimental group 4 & 0.66 \\
\hline \multirow{6}{*}{$\begin{array}{l}\text { 3) the chosen teaching methods and } \\
\text { techniques are appropriate for the } \\
\text { lesson objectives }\end{array}$} & \multicolumn{2}{|c|}{ 2016-2017 academic year } \\
\hline & Experimental group 1 & 0.77 \\
\hline & Experimental group 2 & 0.7 \\
\hline & \multicolumn{2}{|c|}{ 2017-2018 academic year } \\
\hline & Experimental group 3 & 0.8 \\
\hline & Experimental group 4 & 0.7 \\
\hline
\end{tabular}

(to be continued) 


\section{Results of experimental participants' lesson planning skills attainment} (continued)

\begin{tabular}{|c|c|c|}
\hline \multirow{6}{*}{$\begin{array}{l}\text { 4) the language learning tasks are } \\
\text { formulated properly }\end{array}$} & \multicolumn{2}{|c|}{ 2016-2017 academic year } \\
\hline & Experimental group 1 & 0.78 \\
\hline & Experimental group 2 & 0.72 \\
\hline & \multicolumn{2}{|c|}{ 2017-2018 academic year } \\
\hline & Experimental group 3 & 0.81 \\
\hline & Experimental group 4 & 0.7 \\
\hline \multirow{6}{*}{$\begin{array}{l}\text { 5) the lesson plan is written in foreign } \\
\text { and native languages clearly and } \\
\text { accurately }\end{array}$} & \multicolumn{2}{|c|}{ 2016-2017 academic year } \\
\hline & Experimental group 1 & 0.78 \\
\hline & Experimental group 2 & 0.76 \\
\hline & \multicolumn{2}{|c|}{ 2017-2018 academic year } \\
\hline & Experimental group 3 & 0.79 \\
\hline & Experimental group 4 & 0.71 \\
\hline
\end{tabular}

The average coefficients of learning outcomes for experimental groups were as follows: group $1-0.77$; group 2-0.67; group 3-0.77; group $4-0.68$.

According to our hypothesis, project-based method can be used to train pre-service teachers to deliver methodological performance as a specific kind of a foreign language and culture teachers' professional activities, which is "in planning, designing, and constructing, investigating teaching tools $\langle\ldots\rangle$, devising, selecting and using teaching aids that need constant improvement (Shagan, 2010, pp. 11-12)."

To verify the relevance and effectiveness of applying a project-based method in building and improving pre-service foreign language and culture teachers' methodological skills, we used in the educational experiment a series of professional methodological project tasks. Examples of project-based methodological tasks are included in Appendix 3.

Experimental participants' projects were analysed and evaluated on the basis of aims, content, language, culture, planning, teaching strategies and resources criteria. The results are given in Table 4.

Table 4

Assessment results of experimental participants' methodological performance

\begin{tabular}{|l|l|}
\hline Experimental groups & \multicolumn{1}{c|}{ Learning outcomes coefficient } \\
\hline \multicolumn{2}{|c|}{$2016-2017$ academic year } \\
\hline Experimental group 1 & 0.71 \\
\hline Experimental group 2 & 0.68 \\
\hline Experimental group 3 & 0.74 \\
\hline Experimental group 4 & 0.66 \\
\hline
\end{tabular}

The average coefficient of learning outcomes for experimental groups 1 and 3 amounted to 0.73 , and for experimental groups 2 and 4 it was 0.67 .

\section{Discussion}

The experimental research showed that for pre-service foreign language and culture teachers, tests as the means for implementing test method are 1) learning tools; 2) means of controlling educational and cognitive activities; 3) self-assessment tools for evaluating the process and outcomes of methodological knowledge acquisition. Using tests for students' self-assessment ensures, as Gabbasova (2012) believes, the organisation and functioning of internal feedback on the quality and completeness of learning retention, difficulties, and drawbacks. Our experimental participants self-corrected their learning outcomes by relearning theoretical material and performing a thematic test at the end-of-module stage.

Autonomous methodological knowledge acquisition with the use of ICT presupposes the following students' activities: 1) reading various scholar methodological works by domestic and foreign scientists in the field of language and culture teaching methodology, which may be retrieved from authoritative Internet sources (for example, with the purpose of analysing modern approaches, technologies, tools, techniques, etc. of teaching foreign languages and cultures), publications or documents of the Council of Europe Education 
Department; 2) analysing different teacher manuals, lesson plans, authentic audios and videos, course materials, etc. from authoritative web sources devoted to teaching foreign languages; 3 ) performing training and/or evaluation tests aimed at assessing target knowledge. Good command of methodological knowledge is the basis for developing pre-service foreign language and culture teachers' methodological skills.

According to our positive pedagogical experience and results of the experimental data analysis, we can claim that applying a case study method in teacher training enables developing pre-service foreign language and culture teachers' methodological skills, particularly the skills of analysing and optimal solving professional situations. The methodological skills that are built and improved in the course of solving professional methodological cases endow pre-service teachers with the expertise to plan classroom activities. Among such skills, there are abilities to analyse and correct methodological errors, to compose language lesson plans for the integrated development of linguistic, discourse, lingua-socio-cultural, and strategic competencies.

As was mentioned above, Master's students of two experimental groups simulated their lesson plans at seminars on foreign language and culture teaching methods. Such important methodological skills of preservice teachers as their ability to teach lessons for integrated evolving of linguistic, discourse, lingua-sociocultural, and strategic competencies in accordance with self-generated lesson plans, provide the basis for effective realisation of professional actions. Thus, various real-life professional situations that require a practical demonstration of the attained methodological knowledge and teaching skills should be modelled and simulated in the classroom to foster pre-service teachers' methodological skills. A professional roleplaying game is one of the sufficient teacher training techniques to meet these challenges. On the basis of the results of the educational experiment and taking into account our positive teacher training experience, we recommend that at methodological seminars, Master's students simulate their lesson plans acting as foreign language teachers. In professional games, while playing the roles of teachers, students have the opportunity to test the generated materials, analyse the effectiveness of their lesson plans, investigate the methodological expediency of teaching methods, techniques and tools used, examine their language behaviour, etc.

The assessment objects for evaluating pre-service foreign language and culture teachers' methodological expertise are their abilities to determine sequential stages for building target language skills, to choose and use appropriate teaching methods, techniques, and tools, to formulate correctly language learning tasks, etc. The evaluation should be made both by teacher trainers and Master's students (self and peer assessment) while discussing the simulated lessons in the classroom. In this case, pre-service teachers can receive from their trainers and fellow-students valuable recommendations on lesson objectives, teaching methods, techniques, modes, tools, technologies, etc. So by interacting in professional role-playing games, prospective teachers are trained to analyse various methodological situations from teachers' and students' points of view, and discuss effective ways of solving different professional problems (Girod \& Girod, 2008; Niemeyer, Johnson, \& Monroe, 2014; Rudolph, 2008). In this way, students' methodological knowledge and skills of analysis, selection, compilation, design, device, composition, etc. are really synthesised.

Currently, a project-based learning is one of the most progressive teaching methods. It is a constantly developing approach which involves a number of research, search, problem-based, etc. methods and techniques, which are creative by their nature (Zubov, 2009). Researchers distinguish a project-based teacher training as a discrete component of methodological competence (Saraeva, 2011, pp. 114-117; Howard, 2002; Roessingh \& Chambers, 2011). Taking into consideration the results of our experimental teaching, we suggest that the project-based method can be used for methodological training of pre-service foreign language and culture teachers. Methodological agency of pre-service teachers presupposes their ability to generate learning and assessment tools to support the educational process, namely: 1) choosing and selecting course materials; 2) devising exercises, didactic games, scaffolding aids for building students' cross-cultural foreign language communicative competence; 3) creating case studies; 4) writing test questions; 5) designing assessment tasks; 6) producing project-based activities, etc. To implement a project-based method in teacher training process, professional methodological project tasks should be used. They are educational, cognitive, informative, communicative, and creative professional assignments for pre-service foreign language and culture teachers, which should result in their designing classroom or extracurricular activities and tools.

\section{Conclusions}

In the end, we would like to emphasise that the necessity of introducing modern methods and technologies into teacher training is preconditioned by the contemporary needs of our society for efficient specialists with proactive characters. In this regard and in view of our research findings, we recommend applying a test method and ICT to organise pre-service language teachers' self-guarded learning activities over their individual trajectories for target methodological knowledge acquisition, while case study method, 
game method, and project-based method to develop target methodological skills. Obviously, the use of the aforementioned methods and technologies is intended not only to increase the effectiveness of language teacher training but also to bring pedagogical education closer to everyday life and work.

The issues and findings raised in the article indicate that larger implications of this research and avenues for further studies are connected with substantiating the structure and content of the electronic course book for pre-service foreign language and culture teachers aimed at developing their methodological competence with the use of modern educational methods and technologies.

\section{References:}

Azimov, E. G. \& Schukin, A. M. (2009). Novyj slovar' metodicheskih terminov i ponjatij (teorija i praktika obuchenija jazykam) [A new glossary of methodological terms and concepts (theory and practice of language teaching]. Moscow, Russia: IKAR.

Bespalko, V. P. (1968). Opyt razrabotki i ispol'zovanija kriteriev kachestva usvoenija znanij [Experience in developing and applying evaluation criteria for knowledge acquisition]. Sovetskaja pedagogika, 4, 52-59.

Cronbach, L. J. (1951). Coefficient alpha and the internal structure of tests. Psychometrika, 16 (3), 297-334. doi: $10.1007 / \mathrm{bf} 02310555$

Gabbasova, I. N. (2012). Obzor osnovnyih preimuschestv testovoy tehnologii kontrolya znaniy [A review of major advantages of test method of knowledge assessment]. Sovremennyie nauchnyie issledovaniya i innovatsii, 6. Retrieved 16 May 2018 from: http://web.snauka.ru/issues/2012/06/15045.

Girod, M. \& Girod, G. R. (2008). Simulation and the need for practice in teacher preparation. Journal of Technology and Teacher Education, 16 (3), 307-337.

Green, A. (2013). Exploring language assessment and testing: language in action. New York: Routledge. https://doi.org/10.4324/9781315889627.

Heitzmann, R. (2008). Case study instruction in teacher education: opportunity to develop students' critical thinking. School Smarts and Decision Making Education, 128 (4), 523-542.

Howard, J. (2002). Technology-enhanced project-based learning in teacher education: addressing the goals of transfer. Journal of Technology and Teacher Education, 10 (3), 343-364.

Kelch, K. \& Malupa-Kim, M. (2014). Implementing case studies in language teacher education and professional development. ORTESOL Journal, 31, 10-18.

Malyov, A. V. (2015). Nepreryivnaya lingvometodicheskaya podgotovka prepodavatelya inostrannogo yazyika [Continuous lingual and methodological training of a foreign language teacher]. Doctoral thesis, Russia, Nizhniy Novgorod.

Niemeyer, R., Johnson, A., \& Monroe, E. A. (2014). Role play for classroom management: providing a lodestar for alternate-route teachers. The Educational Forum, 78 (3), 338-346. https://doi.org/10.1080/00131725.2014.912373

Nikitina, E. Yu., Afanaseva, O. Yu., \& Fedotova, M. G. (2013). Metodicheskaya kompetentsiya buduschego uchitelya inostrannogo yazyika [Methodological competence of a pre-service foreign language teacher]. Vestnik Chelyabinskogo gosudarstvennogo pedagogicheskogo universiteta, 12, 54-65.

Richards, J. C., Platt, J. T., \& Platt, H. (2002). Longman dictionary of language teaching and applied linguistics (3rd ed.). Essex, England: Longman.

Roessingh, H. \& Chambers, W. (2011). Project-based learning and pedagogy in teacher preparation: staking out the theoretical midground. International Journal of Teaching and Learning in Higher Education, 23 (1), 60-71.

Rudolph, A. (2008). Using role-play and case studies to improve preservice teacher attitudes toward classroom management. Teacher Education and Practice, 21 (3), 329-342.

Saraeva, A. A. (2011). Proektnaya deyatelnost kak neobhodimyiy komponent professionalnoy podgotovki buduschego uchitelya [Project-based activities as an essential component of a pre-service teacher's professional training]. Aktualnyie voprosyi sovremennoy pedagogiki: materialyi Mezhdunarodnoy nauchnoy konferentsii (pp. 114-117). Ufa, Russia.

Shagan, V. S. (2010). Pedagogicheskoe soprovozhdenie protsessa razvitiya metodicheskoy kompetentnosti prepodavatelya kolledzha [Pedagogical maintenance of the process of developing college teacher's methodological competence]. Extended abstract of candidate thesis, Izhevsk, Russia.

Stanley, G. (2013). Language learning with technology: ideas for integrating technology in the language classroom. Cambridge: Cambridge University Press.

Vacca, Y. S. (2014). Collaborative project work development in a virtual environment with low-intermediate undergraduate Colombian students. Profile: Issues in Teachers' Professional Development, 16 (1),29-48. https://doi.org/10.15446/profile.v16n1.37607.

Williams, S. M. (2009). Learning together: project-based learning in the university classroom. College of Integrated Human and Social Welfare Studies, 43, 127-141.

Yurlovskaya, I. A. (2014). Proektnyie tehnologii v realizatsii standartov vyisshego professionalnogo obrazovaniya tretego pokoleniya [Project-based method for implementing standards of higher professional education of the third generation]. Internetzhurnal "Naukovedenie", 2. Retrieved 18 May 2018 from: http://naukovedenie.ru/PDF/127PVN214.pdf

Zubov, A. V. (2009). Metodika primeneniya informatsionnyih tehnologiy v obuchenii inostrannyim yazyikam [Methodology of applying information technologies in teaching foreign languages: a manual for students]. Moscow, Russia: Izdatelskiy tsentr "Akademiya". 


\section{Appendix 1}

\section{Test method and ICT}

Example 1. A matching test item

Test question: As a prospective French teacher, you are aware that the choice of a word denoting method is influenced, first of all, by the nature of the lexical item. So taking into account the nature of the following vocabulary items, choose the most appropriate, in your opinion, ways of their denoting.

1) chien, chat, fleur

2) madame, monsieur

3) continent, touriste, sport, climat

a) inferring word meaning by recognising the meaningful affix

4) désarmement, adroit, impoliment

b) cognate

c) visual aid

d) definition

Example 2. A multiple choice question

Test question: As a prospective foreign language teacher, you know that in project-based learning, students' project competence is developed as their

a) readiness and ability to plan and realise extra-curricular self-guarded learning activities for the purpose of mastering foreign language,

b) readiness and ability, on the assumption of motivation, to organise self-guarded foreign language project-based learning in order to solve certain realistic and meaningful problems,

c) readiness, ability and motivation to plan, implement and analyse self-guarded project-based learning in order to attain and improve foreign language skills.

Example 3. A reordering test type for defining the correct sequence of teacher's methodological actions

Test question: While making a lesson plan for teaching conjugating first group verbs in the present tense, your colleague offers the following sequence of teacher's actions and formulates the assignments for his/her students. If you consider his/her view to be incorrect, suggest your own option, indicating the sequence of teacher's actions by numbers 1 to 4.

A. Trouvez dans le texte les verbes au Présent de l'Indicatif.

B. Mettez les verbes à l'infinitif au Présent de l'Indicatif.

C. Répétez après le speakeur les phrases suivantes: ...

D. Décrivez cette image en employant les verbes au Présent de l'Indicatif.

Example 4. A supply type item / open-ended item

Test question: You, as a prospective foreign language teacher, must be prepared to teach your students reading strategies to foster their reading comprehension skills. Give examples of reading strategies for foreign language learners.

\section{Appendix 2}

\section{Case study method}

Example 1. A professional methodological case for developing skills to analyse a French lesson plan

\section{Description of the methodological situation}

You are a university teacher of French. A trainee teacher was assigned to the study group which you are teaching. During observation teaching practice, you encourage him/her to teach certain extracts from the lesson plan. Analyse the student teacher's lesson plan for building first-year Bachelor students' spelling skills using the following criteria: 1) the teaching objectives statements are written accurately; 2) the lesson stages relate to the teaching objectives; 3) the chosen teaching methods and techniques are appropriate for the lesson objectives; 4) the language learning tasks are formulated properly; 5) the lesson plan is written in foreign and native languages clearly and accurately. The maximum number of points awarded for each criterion is 5 . Present your analysis results at the seminar.

\section{Reference materials for solving the methodological situation}

\section{Lesson plan for building French spelling skills}

Teaching objectives:

1) educational objectives: to provide French spelling knowledge; to build and improve spelling skills of using trait d'union;

2) lingua-socio-cultural objectives: to develop the ability of sociolinguistic observation, comparison, analysis, and reflection;

3) developmental objectives: to elaborate spelling advertency, orthographic perception, visual perception, visual memory, involuntary and voluntary attention, linguistic intuition;

4) educative objectives: to raise interest in orthographic phenomena, patterns, and processes of French spelling knowledge acquisition; to foster conscious and conscientious attitude to language learning;

5) professional objectives: to familiarise students with methods, techniques, tools of building spelling skills.

Materials: test worksheets, auditory dictation.

Resources:

1. Trait d'union (généralités). Retrieved from http://grammaire.reverso.net/5_3_01_trait_dunion.shtml.

2. Trait d'union. Retrieved from http://blog01eso.blogspot.com/2015/06/trait-dunion.html.

\section{Process}

Stage 1. Representation of orthographic knowledge

Technique 1. Teacher explanation of the hyphen use rules.

Professeur: Aujourd'hui nous apprenons les règles d'emploi de trait d'union. Le trait d'union sert à marquer qu'il existe un lien étroit entre deux termes. Ce lien peut être un lien lexical (mots composés) ou un lien syntaxique (entre le verbe et le pronom qui le suit). Le 
trait d'union se place entre un pronom personnel et même (moi- même), dans les mots composées après demi et semi/ex/non/pro (un demi-litre), dans les mots composés avec ci ou la (ci-dessus, ces jour-là, là-bas, celui-ci), entre le verbe et un pronom sujet à la forme interrogative (où allez-vous?), entre le verbe et un pronom complément à l'impératif (pensez-y), dans les noms des nombres composés inférieures à cent et juxtaposés (soixante-six).

Stage 2. Guided practice

Technique 2. Students are answering multiple choice questions autonomously.

Professeur: Je vous donne les cartes. Soulignez la variante correcte dans chaque phrase proposée.

1. Combien y a-t-il / y-a-t-il / y a t-il de livres dans cette bibliothèque? 2. Rappelez le moi / Rappelez-le moi / Rappelez-le-moi,etc.

Technique 3. Students are self-checking their tests.

Professeur: Regardez le tableau. Ici vous voyez les réponses correctes. Qui a fait des fautes?

Etudiant 1: J'ai fait une faute.

Professeur: Corrigez-la et formulez la règle d'emploi le trait d'union dans ce cas-là.

Technique 4. Auditory dictation.

Professeur: Ecoutez et écrivez dans vos cahiers en observant les règles d'emploi de trait d'union.

1. Comment peut-on ouvrir cette porte? 2. Regardez ce tableau et celui-là. 3. Avant le premier étage il ya le rez-de-chaussée. 4. Il y a soixante-treize livres dans cette bibliothèque. 5. As-tu déjà fréquenté cet endroit-ci? 6. Donne-le-lui! 7. Un demi-kilo de pommes, s'il vous plaît!

\section{Criteria for evaluating the elaborated solution of the methodological situation:}

1) correct solution of the methodological situation -5 points, 2) independence -5 points.

Example 2. A professional methodological case for developing methodological skills of videotaped lesson analysis 1. Description of the methodological situation

You are a French teacher concerning yourself in observing your practicing colleagues in order to increase your own methodological competence. Analyse a videotaped French lesson for the elementary classroom. Define its objectives and teaching methods and techniques used by a colleague. Present your analysis results at the seminar.

\section{Reference materials for solving the methodological situation}

Reconnaître et identifier les phonèmes [Video file]. Retrieved from: https://www.youtube.com/watch?v=HN5A4H-P2tg.

\section{Criteria for evaluating the elaborated solution of the methodological situation:}

1) the student correctly identifies lesson objectives -5 points, 2) the student correctly identifies teaching methods and techniques -5 points.

Example 3. A professional methodological case for developing skills to create a French lesson plan

\section{Description of the methodological situation}

You are a prospective French teacher. You are to make your own video-based lesson plan for developing your first year students' listening skills for detailed understanding of video messaging. To do this, you need to analyse the video material and prepare for demonstrating it to your students. Identify key areas where students may have difficulty understanding, devise video-based activities and assessment tasks. Compose a short lingua-socio-cultural off-screen commentary. Present your video-based lesson plan at the seminar.

\section{Reference materials for solving the methodological situation}

Louis Vuitton City Guide 2011 - Paris, le Saint-Honoré [Video file]. Retrieved from http://www.podcastfrancaisfacile.com/ podcast/2010/11/louis-vuitton-city-guide-2011-paris-le-saint-honor\%C3\%A9.html.

\section{Criteria for evaluating the elaborated solution of the methodological situation:}

1) the lesson objectives are formulated correctly; 2) the lesson plan includes pre-viewing, while-viewing, and post-viewing activities; 3) the chosen teaching methods and techniques are appropriate for the pre-viewing aims (generating interest, building confidence, facilitating comprehension); 4) the lingua-socio-cultural off-screen commentary is composed correctly; 5) the lesson plan is written in foreign and native languages clearly and accurately.

\section{Appendix 3}

\section{Project-based method}

Example 1. You are a prospective foreign language and culture teacher preparing training materials for students' self-guarded listening. Choose a podcast for your second-year students to develop their lingua-socio-cultural competence in listening. Using online software programs (e.g. Hot Potatoes) or Web 2.0 tools (e.g. LearningApps), devise pre-listening and after-listening activities for podcasting.

Example 2. You are a prospective foreign language and culture teacher. Devise multiple choice questions of different kinds for thematic-based vocabulary assessment of your first-year students. Choose any topic.

Example 3. You are a prospective foreign language and culture teacher planning to organise project-based learning activities of your third-year students. Prepare a methodological passport for the socio-cultural project aimed at producing travel brochure for foreign tourists arriving in the country of residence. Describe the project stages, teacher's functions and students' activities at each stage. Choose appropriate training materials for students to complete their project tasks. Determine the criteria for evaluating students' project products. 